\title{
Management of waste containing very low activity levels under conditions of uncertainty
}

\author{
M.K. Sneve ${ }^{1}$, O.A. Kochetkov², V.V. Romanov ${ }^{3}$, P. Strand ${ }^{1}$, V.G. Barchukov², \\ S.G. Monastyrskaya ${ }^{2}$, N.P. Sajapin ${ }^{2}$, B.E. Serebryakov ${ }^{2}$ and M.P. Semenova ${ }^{2}$ \\ ${ }^{1}$ Norwegian Radiation Protection Authority, PO Box 55, 1332 Osteras, Norway \\ ${ }^{2}$ Burnasyan Federal Medical Biophysical Centre Federal Medical-Biological Agency, \\ 123182, Zhivopisnaya 46 Moscow, Russia \\ ${ }^{3}$ Federal Medical-Biological Agency of Russia, 123182 Volokolamskoe Shosse, \\ 30 Moscow, Russia
}

\begin{abstract}
The problem of low level waste management is currently the issue of the day. In the context of the present work, these wastes are referred to as very low level wastes (VLLW), similar to some foreign States and like in IAEA publications. The solution of VLLW management is possible through introduction of this waste category into the system of the national classification. The waste management problem solving at SevRAO facility requires elaborating provisions relating to VLLW management procedure, variants of release from regulatory control, disposal options, sitting the disposal landfills in terms of SevRAO features, forming both radiation situation and occupational doses. A conclusion is made that industrial waste containing man-made radionuclides with up to $30 \mathrm{kBq} / \mathrm{kg}$ specific activity may be safely disposed at VLLW landfill in Andreeva Bay and Gremikha and the level of the industrial waste clearance from the radiation control corresponds to $0.3 \mathrm{kBq} / \mathrm{kg}$.
\end{abstract}

\section{INTRODUCTION}

The problem of low level waste management is currently the issue of the day. Different data demonstrate that the amount of such waste is up to $2 / 3$ of all radioactive wastes (RW) being generated at radiation hazardous facilities. Therefore, a set of measures for the safe management of such waste category is to be developed. In some States, this waste category is referred to as «very low level waste» (VLLW). Generally, these are wastes with activity levels, which are 100 times higher than the level of RW clearance from the regulatory control, but lower than the lower bound of the specific activity level, which permits to consider the waste as radioactive.

Now, there is no unified opinion on management of this industrial waste category. In Sweden, the special landfill had been arranged for such waste disposal near NPP in Oscarshamn, where very low level wastes are being disposed from all radiation hazardous facilities. In France, this waste is not conveyed to conventional waste disposal landfill, instead it is stored within industrial sites, where it has been generated, or it is transported into RW disposal facility in La-Aube. In Japan, with the purpose of VLLW disposal resulted from the research JPDR reactor dismantlement, a special disposal facility has been built within the industrial site.

The solution of VLLW management, both in the world practice and in Russia is possible through introduction of this waste category into the system of the national classification. Analysis of radioactive waste categorization is the evidence that the Russian legislative base has a basis to solve the problem of such waste category disposal (Para.3.11 OSPORB-99) [1]. Nevertheless, a lack of regulative and guidance documents permitting to determine the procedure of this legislative base application, hampers an introduction of VLLW management system into everyday practice. 


\section{ANALYSIS OF SEVRAO SPECIAL FEATURES}

VLLW management problem has arisen in Russia critically in the course of nuclear legacy problem solving, especially during decommissioning and remediation of the ex-Navy shore technical bases (sites for spent nuclear fuel and radioactive waste temporary storage (SNF and RW STS)), including those located in the Russian Northwest (Andreeva Bay and Gremikha village). The situation of the industrial waste management included in the VLLW category at the SNF and RW STS is rather complicated, because the design of these radiation hazardous facilities contained neither RW management technologies, nor technologies of the industrial waste management during the postoperational period. These facts together with the below data generate special features of VLLW management at SevRAO facilities:

- at the modern radiation hazardous enterprises, such as NPP, RW and industrial waste management is aimed at sorting and disposal of new generating wastes, while at SNF and RW STS this activity deals with legacy wastes;

- an isotope compositions are rather different: NPP waste is characterized by the low content of $\mathrm{Sr}^{90}$ and high content of short-lived isotopes, in particular $\mathrm{Co}^{60}$; at SevRAO, the waste isotope composition consists mainly of $\mathrm{Sr}^{90}$ and $\mathrm{Cs}^{137}$, where $\mathrm{Sr}^{90}$ quota is about $20 \%$;

- waste disposal facilities at NPP, are generally located within Health Protection Zones (PHZ), while at SevRAO they are arranged on the industrial site.

The mentioned features of SevRAO facility define the search of the science based specific technologies of SNF and RW management including VLLW management.

In addition to differences in waste management technologies, the radiation situation on the industrial sites is rather different too. At NPP, noticeable contamination of the site is practically absent, while at SNF\&RW STS, in Andreeva Bay in particular, according to NIKIET and SRC-IBPh experimental data, soil sample activities are in the range $10^{2}-10^{4} \mathrm{~Bq} / \mathrm{kg}$, and at some parts of the site (near the brook in the vicinity of Building 5, close to the Blocks of dry storage facilities), specific activity of the soil reaches $10^{5} \mathrm{~Bq} / \mathrm{kg}$.

It should also be noted that at the area adjacent to SevRAO, there are no settlements, agricultural grounds, forestry lands and water media, which the public could use to get foods.

\section{JUSTIFICATION OF THE MAIN SAFETY CRITERIA}

The data presented illustrates that the waste management problem solving at SevRAO facility requires elaborating provisions relating to VLLW management procedure, variants of release from regulatory control, disposal options, sitting the disposal landfills in terms of above-mentioned features, forming both radiation situation and occupational doses. With this purpose, the regulative guideline document has been developed for SevRAO facility in compliance with the requirements of para.1.3. SPORO-2002 [4]; this document is the Guidance «Hygienic requirements for the industrial waste management » at the Federal state unitary enterprise «Northern federal enterprise for radioactive waste management » [5].

The main issues of the document are occupational, public and environmental protection. The document justifies and introduces the base radiation protection criteria - specific activity boundaries for VLLW category, which according to OSPORB-99 Para 3.11.4, are within the range $0.3 \mathrm{kBq} / \mathrm{kg}$ $100 \mathrm{kBq} / \mathrm{kg}$ for $\beta$-emitting radionuclides.

Having in mind the fact that beta-emitting radionuclides $\mathrm{Sr}^{90}$ and $\mathrm{Cs}^{137}$ at a ratio of $20: 80$ produce the main radiological problem at SevRAO facility, a level of release from the radiation control of a metal intended for re-melting can be determined more precisely. At that, one should remember that the Hygienic regulations "Contents of man-made radionuclides in metals" (GN 2.6.1.2159-07) [6], recommend to release metals with specific activity levels of $10 \mathrm{kBq} / \mathrm{kg}$ - for $\mathrm{Sr}^{90}$ and $1 \mathrm{kBq} / \mathrm{kg}$ - for $\mathrm{Cs}^{137}$ intended for re-use, from the radiation control. Accounting the quota of each radionuclide, the average specific activity level permitting to release the metal from SevRAO facility from the regulatory 


\begin{tabular}{|c||c||c|c||}
\hline Waste category & $\begin{array}{c}\text { Specific } \\
\beta \text {-activity, } \mathrm{kBq} / \mathrm{kg}\end{array}$ & $\begin{array}{c}\text { Surface contamination, } \\
\beta \text {-particles/min* } \mathrm{cm}^{2}\end{array}$ & $\begin{array}{c}\text { Dose rate at } 0.1 \mathrm{~m} \text { from the } \\
\text { surface of the package, } \\
\mu \mathrm{Sv} / \mathrm{h}\end{array}$ \\
\hline \hline Exempt wastes & $\leq 0.3$ & $\leq 50.0$ & $\begin{array}{c}\text { Not more than } 0.1 \text { exceeding } \\
\text { of the natural radiation } \\
\text { background, typical for the } \\
\text { particular place }\end{array}$ \\
\hline \hline VLLW & $0.3-12.0$ & $50.0-500.0$ & $0.1-1.0$ \\
\hline
\end{tabular}

Figure 1. Criteria of SevRAO industrial waste ascription to the VLLW category.

control, is $1,2 \mathrm{kBq} / \mathrm{kg}$. For the rest industrial wastes the level of clearance from the radiation control must not exceed $0,3 \mathrm{kBq} / \mathrm{kg}$, according to OSPORB-99.

The upper bound of the industrial waste ascription to VLLW category corresponds to the lower LLW bound. According to SPORO-2002, this value must not exceed the specific activity of minimum significance (SAMS). Taking into account $\mathrm{Sr}^{90}$ and $\mathrm{Cs}^{137}$ radionuclide composition and the quota of each radionuclide at SevRAO, the SAMS value for the wastes, which might be ascribed to VLLW category, is $12 \mathrm{kBq} / \mathrm{kg}$ (Fig. 1).

The question of interest is: may LLW be disposed at the VLLW landfill? This question arises because $12 \mathrm{kBq} / \mathrm{kg}$ regulative requirements limit significantly operator's activity and result in unwarrantedly increased costs of RW disposal. The international practice (Sweden, USA etc.) and our origin calculations show that the upper bound of the wastes containing man-made radionuclides, which wastes are to be disposed, may be increased closer to LLW, only on condition that:

- the waste does not contain large amount of transuranium and alpha-emitting radionuclides, limiting by $\mathrm{T}_{1 / 2}$ clearance from the regulatory control within some foreseeable period;

- the containment barriers assure safe storage of this waste for the period of their potential hazard;

- the planned time of the landfill release from the regulatory control ensures decay of radionuclides containing in the disposed waste up to $0.3 \mathrm{kBq} / \mathrm{kg}$ specific activity level or up to the higher values, but at that the annual effective dose to the critical group of population must not exceed $10 \mu \mathrm{Sv} /$ year. Having in mind these circumstances (RW isotope composition is defined by $\mathrm{Cs}^{137}$ and $\mathrm{Sr}^{90}$, at a ratio of $80: 20$, containment barriers of the landfill are being produced similar to the Swedish ones and time of release from the regulatory control with respect to the site under remediation according to the Conception being developed in Rosatom is 100 years), industrial waste containing man-made radionuclides with up to $30 \mathrm{kBq} / \mathrm{kg}$ specific activity may be safely disposed at VLLW landfill in Andreeva Bay and Gremikha (Fig. 2).

\section{RELEASE OF THE VLLW LANDFILL FROM THE RADIATION CONTROL}

Our origin calculations showed that the waste specific activity at the landfill as a whole in 100 years would be $3.0-0.3 \mathrm{kBq} / \mathrm{kg}$, taking into account radionuclide decay and uniform distribution of radionuclides over the whole landfill volume.

Future use of the VLLW landfill can be implemented according to one of the following 3 scenarios with safety justification and provided approval of the bodies responsible for performance of the state sanitary epidemiological supervision: 


\begin{tabular}{|c|c|c|c|c|}
\hline $\begin{array}{c}\text { Radionuclide } \\
\text { specific activity } \\
\text { in the package, } \\
\mathrm{kBq} / \mathrm{kg}\end{array}$ & \begin{tabular}{|c} 
Maximum \\
radionuclide specific \\
activity in the \\
package, \\
$\mathrm{kBq} / \mathrm{kg}$
\end{tabular} & $\begin{array}{l}\text { Levels of VLLW } \\
\text { superficial } \\
\beta \text {-contamination, } \\
\text { part } / \mathrm{min}^{*} \mathrm{~cm}^{2}\end{array}$ & $\begin{array}{c}\text { Equivalent dose } \\
\text { rate, } \\
\mu \mathrm{Sv} / \mathrm{h}\end{array}$ & $\begin{array}{c}\text { Maximum } \\
\text { content of } \\
\text { long-lived } \\
\alpha \text {-active } \\
\text { radionuclides, } \\
\%\end{array}$ \\
\hline $0.3-30.0$ & $<100.0$ & $50.0-500.0$ & $\begin{array}{c}<1.0 \text { at } 0.1 \\
\text { meter distance } \\
\text { from the } \\
\text { package }\end{array}$ & 0.1 \\
\hline
\end{tabular}

Figure 2. Characteristics of RW acceptability being conveyed to VLLW disposal landfill, at the isotope composition ${ }^{90} \mathrm{Sr}(20 \%)$ and ${ }^{137} \mathrm{Cs}(80 \%)$.

- clearance from regulatory control provided that the specific activity being averaged by the whole landfill, including the containment barriers, does not exceed $0.3 \mathrm{kBq} / \mathrm{kg}$;

- limited use of the disposed waste, the activity level of which is lower than SAMS, in the economic activity;

- "brown lawn" arrangement on the industrial site keeping, at the same time, the landfill under conservation there.

According to recommendations of the international organizations, the VLLW disposal landfill, which is being arranged within the industrial site, when releasing from the regulatory control must assure that the public dose constraint is not higher than $0.3 \mathrm{mSv} / \mathrm{year}$ (Fig. 3).

\begin{tabular}{|c|c|c|c|c|}
\hline Full clearance & $\begin{array}{l}\text { Clearance level } \\
\text { non-exceeding by } \\
\text { specific activity }\end{array}$ & \multirow{2}{*}{$\begin{array}{l}\text { Non-exceeding of } \\
\text { the annual effective } \\
\text { dose to the critical } \\
\text { group of the } \\
\text { population } \\
\leq 10 \mu \mathrm{Sv}, \\
\text { collective dose } \\
\leq 1 \text { man-Sv }\end{array}$} & \multirow{2}{*}{$\begin{array}{l}\text { Non-exceeding } \\
\text { of the public } \\
\text { exposure level at } \\
\text { unintended } \\
\text { human intrusion } \\
\leq 0.1 \mathrm{mSv} / \text { year } \\
\text { collective dose } \\
\leq 1 \mathrm{man}-\mathrm{Sv} \\
\text { /year }\end{array}$} & \multirow{2}{*}{$\begin{array}{l}\text { Non- } \\
\text { exceeding of } \\
0.3 \mathrm{mSv} / \text { year } \\
\text { public dose } \\
\text { constraint } \\
\text { after the } \\
\text { closure }\end{array}$} \\
\hline Limited clearance & $\begin{array}{c}\text { Excess clearance } \\
\text { level }\end{array}$ & & & \\
\hline
\end{tabular}

Figure 3. Criteria of the VLLW landfill release from regulatory control.

\section{CONCLUSIONS}

Summarizing all above mentioned, we could conclude that:

1. The Russian sanitary legislation envisages the general system of the waste management, which waste corresponds to "very low level waste" (VLLW) international category.

2. To harmonize terminology of the Russian regulative basis with the international one, the industrial waste containing man-made radionuclides with specific activity levels lower than LLW, but higher the level of exemption from the radiation control, is reasonable to separate into VLLW category. 
3. The main criteria defining the bound values for this waste category (the specific activity levels) are being specified in OSPORB-99 Para. 3.11. In respect to SevRAO conditions, the level of the industrial waste clearance from the radiation control corresponds to $0.3 \mathrm{kBq} / \mathrm{kg}$, while the upper level of the specific activity of the allocated waste must not be higher than the averaged over the whole landfill values $-30 \mathrm{kBq} / \mathrm{kg}$.

\section{Acknowledgments}

The authors would like to express their thanks and appreciation to the Norwegian Radiation Protection Authority for support implemented through the Norwegian Plan of Actions, which rather promotes improvements of radiation protection and nuclear safety at facilities of the Russian Northwest. The authors also thank Mr. Graham M. Smith for his assistance and useful discussions in the course of this work implementation, and Mr. Christian Deregel for valuable relevant materials provided.

\section{References}

[1] Sanitary rules «The Main Sanitary Rules of Radiation Protection Assurance » OSPORB-99, SP 2.6.1.799-99, approved by the RF State Chief medical officer 27.12.1999.

[2] Final report No. 104/5 « Results of Radiation Measurements on-site SNF and RW STS in Andreeva Bay». MCEB, Moscow, 2002.

[3] M. Sneve, M. Kiselev, O. Kochetkov. Radiation Regulation Improvement during Remediation of the Nuclear Legacy Facilities in the Northwest Russia. Final report on FMBA of Russia and NRPA cooperation at the end of 2006. NRPA Proceedings, 2007, No.12, 83 pp.

[4] Sanitary rules « Sanitary Rules of Radioactive Waste Management» SPORO-2002, SP 2.6.1.116802, approved by the RF State Chief medical officer 16 October 2002.

[5] The Guidance «Hygienic Requirements for the Industrial Waste Management» at the Federal State Unitary Enterprise «Northern Federal Enterprise for Radioactive Waste Management» (RONAO SevRAO-08). Approved by the Deputy Head of the Federal medical-biological agency, the RF State Chief medical officer on facilities and sites serviced V.V. Romanov 24.01.08.

[6] Hygienic regulations «Contents of Man-made Radionuclides in Metals», GN 2.6.1.2159-07, approved by the RF State Chief medical officer 08 February 2007. 
